\title{
Oil and Gas Development in Western Canada IN THE NeW MillenNiUM: THE ChaNGING Legal FRAMEWORK IN THE NORTHWEST TERRITORIES, THE YUKON, AND OFFSHORE BRITISH COLUMBIA
}

\author{
SANDY CARPENTER, CeCilia A. Low, \\ AND JOHN OLYNYK'
}

This article explores recent changes with respect to oil and gas development in Western Canada. It explains the new legal regime being implemented to regulate oil and gas development in the Northwest Territories, the Yukon, and British Columbia. The authors provide an analysis of how this legal regime differs from the previous regulatory framework, and they give an in-depth analysis of how this impacts on various actors in the industry.

\begin{abstract}
Cet article explore les récents changements qui concernent l'industrie pétrolière el gazière dans l'Ouest canadien. Les auteurs y expliquent le nouveau régime juridique qui est mis en place dans le but de réglementer l'expansion du secteur pétrolier et gazier dans les Territoires du Nord-Ouest, au Yukon et en Colombie-Britannique. Les auteurs font l'analyse des différences de ce régime juridique avec l'ancien cadre de réglementation et examinent en profondeur l'incidence de ces changements sur les differents acteurs de cette industrie.
\end{abstract}

\section{TABLE OF CONTENTS}

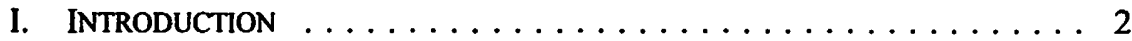

II. THE NORTHWEST TERRITORIES $\ldots \ldots \ldots \ldots \ldots \ldots \ldots \ldots \ldots$

A. DEVElopMent of the CuRRENT Regime(s) $\ldots \ldots \ldots \ldots \ldots 3$

B. THE CURRENT REGULATORY REGIME(S) IN THE NORTHWEST TERRITORIES $\ldots \ldots \ldots \ldots \ldots \ldots \ldots 6$

C. The InUVialuit SetTlement Region $\ldots \ldots \ldots \ldots \ldots \ldots 7$

D. THE Mackenzie Valley $\ldots \ldots \ldots \ldots \ldots \ldots \ldots \ldots \ldots$

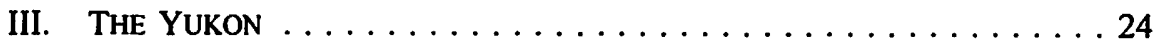

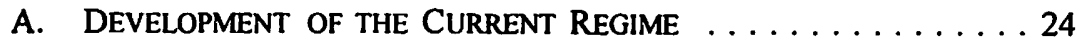

B. THE CURRENT REgULATORY REgIME IN THE YUKON $\ldots \ldots \ldots 27$

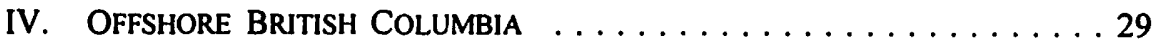

A. HISTORY . . . . . . . . . . . . . . . . . . . . . 29

B. The Moratoriums $\ldots \ldots \ldots \ldots \ldots \ldots \ldots \ldots \ldots \ldots \ldots \ldots$

C. CURRENT STATUS OF BRITISH COLUMBIA OfFSHORE ACTIVITY ................. 31

D. THE FUTURE OF BRITISH COLUMBIA OFFSHORE OIL

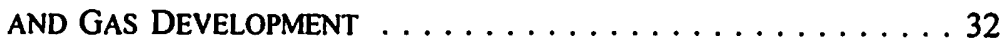

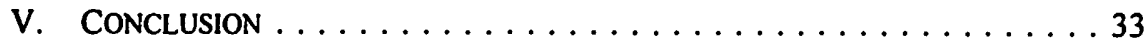

Sandy Carpenter and Cecilia Low are partners at the Calgary office of Lawson Lundell. John Olynyk is an associate of the Calgary office. The authors would also like to thank Christian $\mathrm{Cu}$, an associate at the firm's Vancouver office, and Cydney Elofson, an associate at the Calgary office, for their assistance. 


\section{INTRODUCTION}

It would be difficult, if not impossible, to ignore the recent flurry of newspaper reports, studies, and other materials touting the Northwest Territories (including the Mackenzie Delta and Beaufort Sea) and the Yukon as the next (if not new) frontier for oil and gas activity in Canada. Even renewed activity in the offshore area of British Columbia has been suggested as a possibility in the new millennium.

Exploration for, and development of, oil and gas in the Northwest Territories, the Yukon, and offshore British Columbia presents an array of physical, social, economic, and legal challenges. While some of the components of the legal regimes in these areas are similar to those in other jurisdictions, the overall legal frameworks and the influence of what some might consider non-legal issues differ significantly from other existing regimes. In addition, the relatively recent renewal of activity in these areas, and the recent enactment of some of the components of these regimes, means that parts of these regimes are virtually untested, both practically and legally.

The purpose of this article is to provide an overview of the legal regimes regulating oil and gas development in the Northwest Territories, the Yukon, and offshore British Columbia. The intent is not to review in detail every legal requirement in these jurisdictions. Rather, it is to provide a framework for understanding these regimes and the primary influences that gave rise to, and continue to affect, these regimes.'

While these underlying influences are similar in the Northwest Territories and the Yukon, the resulting legal frameworks in these regions differ substantially. As a result, we will examine each of these jurisdictions separately. The first part of this article discusses the Northwest Territories. The second part focuses on the Yukon. In each of these parts we provide an overview of the development of the current regime and the primary influences on them, and we then go on to discuss the current regulatory regime in each jurisdiction.

The third part of the article provides a brief overview of the history and current legal status of oil and gas development off the coast of British Columbia. We also examine the potential impact of land claims and the issue of jurisdiction on the development of these resources.

The article concludes with some comments identifying common themes in these different jurisdictions and some of the potential implications of these themes for the oil and gas industry.

I Given the broad nature of this topic and the many associated issues that might be covered, we have chosen to focus on the regulatory regimes applicable to the upstream aspects of the oil and gas industry. In addition, we will not discuss in any detail general environmental regulation or royalty regimes. 


\section{THE NORTHWEST TERRITORIES}

\section{A. Development of the CurRent Regime(S)}

The starting point for understanding the current regulatory regime(s) in the Northwest Territories is a trite but fundamental proposition. The Northwest Territories do not have independent constitutional status; thus, unlike the provinces, they do not own their natural resources, and their only law-making powers are delegated from the federal government. Consequently, until very recently, Canada was the owner of, and had sole jurisdiction over, oil and gas resources in the Northwest Territories.

Under this framework, different aspects of oil and gas development in the Northwest Territories have been administered by the Northern Oil and Gas Directorate of the Department of Indian Affairs and Northern Development ("DIAND") and the National Energy Board ("NEB"). Since 1985, this has taken place under the Canada Petroleum Resources $\mathrm{Act}^{2}$ and the Canada Oil and Gas Operations $\mathrm{Act}^{3}$ and their accompanying regulations.

Other pieces of federal legislation regulated land and water resources. Land use was administered by DIAND (although through a different department than oil and gas interests) under the Territorial Lands $A c t^{4}$ and accompanying regulations. Licences permitting the use of water and/or the deposit of waste were granted by the Northwest Territories Water Board under the Northwest Territories Waters Act ${ }^{5}$ and regulations.

This legal framework has changed dramatically over the last fifteen years. The negotiation and implementation of land claims agreements in the Northwest Territories has created new surface and subsurface resource land owners, as well as new institutions with jurisdiction over various activities. These land claim agreements have been the dominant influence on the current legal regime affecting oil and gas development in the Northwest Territories.

The first of these agreements, the Inuvialuit Final Agreement, was concluded in $1984 .^{6}$ Somewhat ironically, the incentive for reaching this agreement was what was then thought to be the imminent development of the Beaufort Sea. Under the IFA, the Inuvialuit were granted fee simple title to certain lands, including the subsurface resources under these lands, which includes oil and gas rights (referred to as "s. 7(1)(a) lands"). ${ }^{7}$ The Inuvialuit

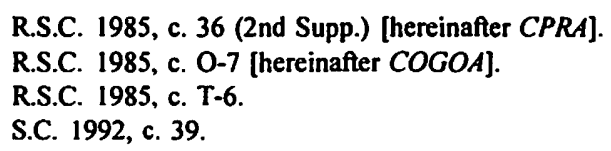

DIAND, The Western Arctic Claim: The Inuvialuit Final Agreement (Ottawa: Indian and Northern Affairs Canada, 1984) [hereinafter IFA]. The Inuvialuit Settlement Region may be found online: Government of Northwest Territories <http://www.gov.nt.ca/RWED/maps/west.htm> (last accessed 1 May 2001) [hereinafter Settlement Map].

7 Ibid., s. $7(1)$ (a). The Inuvialuit received title to 5,000 square miles of surface and subsurface lands. 4,200 square miles is in blocks near the six Inuvialuit communities. An additional 800 square miles is in the Cape Bathurst area. 
were also granted fee simple title to other lands not including oil and gas or other subsurface resources, except sand and gravel (referred to as "s. 7(1)(b) lands"). ${ }^{8}$

This transfer of ownership immediately changed the legal landscape in the Northwest Territories. The Inuvialuit were now in a position to grant subsurface rights under $\mathbf{s}$. $7(1)$ (a) lands outside of the pre-existing federal regime. In addition, if a resource developer needs to use s. 7(1)(b) lands, where the Inuvialuit own the surface, the developer must deal directly with the Inuvialuit rather than with the federal government, as done in the past.

The IFA also contains provisions with respect to resource management. These provisions create institutions with certain powers over land and resources, including a requirement that certain developments go through an environmental impact review process. Notwithstanding this, from a structural perspective the IFA did not attempt to replace the pre-existing regime. These new requirements were simply layered on top of the existing regime. Accordingly, when the IFA was brought into force, the enabling legislation did not expressly modify any existing federal or territorial legislation. ${ }^{9}$ It does, however, provide that where there is a conflict between the enabling Act or the IFA and the provisions of any other law in the area covered by the IFA, the enabling Act or IFA prevails to the extent of the inconsistency. ${ }^{10}$

While the IFA includes provisions that enable Inuvialuit institutions to manage the land and resources that were transferred to them, the IFA does not contain comprehensive provisions for self-government. Negotiations are currently underway to address selfgovernment issues in the Inuvialuit area."

The IFA was followed in 1992 by the Gwich'in Comprehensive Land Claim Agreement, and in 1993 by the Sahtu Dene and Métis Comprehensive Land Claim Agreement (the "GFA" and "SFA," respectively). The Gwich' in and Sahtu settlement areas are identified in the Settlement Map. ${ }^{12}$ Due to the similarities between these agreements, they will be discussed together.

Like the IFA, the GFA and SFA provide for the transfer of lands from the federal government to the respective bodies identified in those agreements. ${ }^{13}$ These lands generally fall into one of three categories: Surface/Subsurface, in which the First Nation owns both the surface and subsurface, including oil and gas; Surface Only, in which the First Nation owns the surface only; and fee simple lands that are generally lands selected from previously titled lands in communities where title is held to the surface of these

Ibid., s. $7(1)(b)$. The Inuvialuit received title to 30,000 square miles of surface lands. These lands are distributed throughout the Inuvialuit Settlement Region.

Western Arctic (Inuvialuit) Claims Settlement Act, S.C. 1984, c. 24.

Ibid., s. 4.

DIAND, "NWT Plain Talk" Vol. 1, April 2000.

Settlement Map, supra note 6.

DIAND, Gwich'in Comprehensive Land Claim Agreement (Ottawa: Indian and Northern Affairs Canada, 1992) at c. 18 [hereinafter GFA]; DIAND, Sahtu Dene and Métts Comprehensive Land Claim Agreement (Ottawa: Indian and Northern Affairs Canada, 1993) at c. 19 [hereinafter SFA]. 
lands. ${ }^{14}$ The GFA and SFA also provide for the management of lands and resources transferred under these agreements. As a result, the GFA and SFA continued the changes to the pre-existing legal framework in the Northwest Territories by further dividing the ownership of land and resources between various parties.

However, of perhaps even greater significance to the developing legal framework in the Northwest Territories, the GFA and SFA also contained provisions requiring the establishment of an integrated system of land and water management. ${ }^{15}$ Notwithstanding the geographic scope of the Gwich'in and Sahtu settlement areas, it was agreed aspects of this land and water management system would apply throughout the "Mackenzie Valley." For the purpose of these agreements, this was defined as the whole of the Northwest Territories excluding the Inuvialuit Settlement Region and Wood Buffalo National Park. ${ }^{16}$ Unlike the model used under the IFA, while the GFA and SFA provided that the ultimate jurisdiction for the regulation of land and water should remain with the government, the agreements provided for the creation of new independent public institutions to implement this regime and to replace the existing institutions.

In addition to this land and water management system, each of the GFA and SFA contain express requirements for consultation prior to the commencement of any oil and gas activity. ${ }^{17}$ The GFA and SFA also provide for negotiations with the federal government regarding self-government. ${ }^{18}$ The matters for negotiation under these agreements are primarily internal, and these negotiations have not been concluded.

Each of the GFA and SFA were brought into force under federal legislation. ${ }^{19}$ These statutes do not expressly repeal or amend any existing legislation. They simply provide that where there is any inconsistency or conflict between the enabling Acts or the GFA or SFA, respectively, and the provisions of any law, the enabling Acts or the GFA or SFA prevail. ${ }^{20}$ The majority of the legislative changes necessary to implement the land and water management regime under the GFA and SFA have taken place under the Mackenzie Valley Resource Management Act. ${ }^{21}$

No additional land claim agreements have been reached in the Northwest Territories since 1993. There has been an Agreement in Principle with the Dogrib First Nation

The Gwich'in received title to 6,065 square kilometres (approximately 2,342 square miles) of Surface/Subsurface lands and 16,264 square kilometres (approximately 6,280 square miles) of Surface Only lands. The Gwich'in also received title to 93 square kilometres (approximately 36 square miles) of lands including title only to the mines and minerals on those lands.

The Sahtu received title to 1,813 square kilometres (approximately 700 square miles) of Surface/Subsurface lands and 39,624 square kilometres (approximately 15,299 square miles) of Surface Only lands.

GFA, supra note 13, c. 24; SFA, supra note 13, c. 25.

GFA, ibid., c. 2.1.1; SFA, ibid., c. 2.1.1.

GFA, ibid. c. 21; SFA, ibid., c. 22.

GFA, ibid. c. 5; SFA, ibid. c. 5.

Gwich 'in Land Claim Settlement Act, S.C. 1992, c. 53 [hereinafter Gwich in Act]; Sahtu Dene and Métis Land Claim Settlement Act, S.C. 1994, c. 27 [hereinafter Sahtu Dene and Métis Act].

Gwich 'in Act, ibid., s. 8; Sahtu Dene and Métis Act, ibid., s. 8.

S.C. 1998, c. 25 [hereinafter MVRMA]. 
("Dogrib") in the northeast part of the Northwest Territories. ${ }^{22}$ The Dogrib AIP appears to be consistent with the land and water management principles established for the Mackenzie Valley under the GFA and SFA. Given the lack of proximity of the Dogrib claim to current oil and gas activity, and given the current status of those negotiations, this agreement is not addressed further in this article.

While implementation of the existing land claim agreements has resulted in oil and gas regulatory regimes that are developing differently, there are some fundamental similarities between these agreements:

- they are constitutionally protected under S. 35 of the Constitution Act, $1982,{ }^{23}$

- they bind third parties as well as the Crown and the First Nation; ${ }^{24}$ and

- they establish the basic parameters for the general regulatory framework. ${ }^{25}$

It is expected that any future agreements will contain similar provisions.

These principles are important. The existing land claims agreements have been the primary influence over the changing legal framework in the Northwest Territories. They are also a fundamental part of this framework. As indicated, these agreements did not attempt to amend any existing statutes. However, they did change the pre-existing framework. Therefore, to understand the complete legal framework in the Northwest Territories, companies must be aware of both the express statutory requirements and the specific provisions of the Settlement Agreements, as well as their related requirements.

\section{B. The CURRENT Regulatory Regime(S) IN THE NORThWEST TERRITORIES}

While there are common components to each of these regimes, the differences in the approach to land and resource management in the existing land claim agreements in the Northwest Territories has resulted in a clear distinction in the regulatory frameworks between the Inuvialuit Settlement Region and the Mackenzie Valley, as defined in the Gwich'in and Sahtu Final Agreements and the MVRMA. Accordingly, the regulatory regimes in each of the Inuvialuit Settlement Region and the Mackenzie Valley are discussed separately.

Dogrib First Nation, Comprehensive Land Claim and Self-Government Agreement-in-Principle (Ottawa: DIAND, 2000) [hereinafter Dogrib AIP].

23. Being Schedule B to the Canada ACl 1982 (U.K.), 1982, c. 11.

24 For example, see c. 4(2) of each of the Grich 'in Act and Sahtu Dene and Métis Act, supra note 19. 25 For example, rights and restrictions for access attaching to specific categories or even parcels of land are set out in the Agreements. In addition, the Agreements set out how disputes in respect of access in specific circumstances are to be resolved, and they should provide a means of identifying with whom persons desiring access should consult in order to obtain permission to enter the lands. 


\section{The INUVialuit SeTtlement Region}

The implementation of the IFA has resulted in significant changes to the pre-existing legal regime in the Inuvialuit Settlement Region. However, from an overall regulatory perspective, the IFA did not replace existing laws or institutions; rather, it supplemented that regime. Therefore, the following discussion follows the framework of the pre-existing legal regime.

\section{OIL AND GAS RIGHTS AND OPERATIONS}

\section{a. Crown Oil and Gas Rights and Oil and Gas Operations on Crown Lands}

Crown oil and gas rights and oil and gas operations in the Inuvialuit Settlement Region continue to be managed under the CPRA/COGOA regime. The CPRA governs the allocation of Crown-owned oil and gas rights. Primary responsibility for the ongoing administration of the CPRA in the Northwest Territories lies with the Northern Oil and Gas Directorate of DIAND. The CPRA applies to both onshore and offshore areas in the Inuvialuit Settlement Region. ${ }^{26}$

The CPRA establishes the processes for the issuance and management of oil and gas interests. The first step in this process is a call for nominations for lands to be put up for bid. Prior to initiating a call for nominations, it is the practice of DIAND to consult with the Inuvialuit, other northerners, and the government of the Northwest Territories. The $C P R A$ provides that the minister is to consider any request in respect of particular lands when selecting lands to be put up for bid. ${ }^{27}$ Once a call for nominations is completed, DIAND determines which lands will be put up for bid. DIAND will not include parcels of land in a call for bids where a First Nation has indicated that it does not support oil and gas activity in the area. ${ }^{28}$

A call for bids is required to contain certain specified information. ${ }^{29}$ The call for bids is essentially a unilateral offer of a contract. The submission of a bid is deemed to be an acceptance of the terms and conditions contained in the call, including those in the form of exploration licence attached to the call. ${ }^{30}$ Typical terms and conditions include:

- $\quad$ minimum bid;

- $\quad$ issuance fees;

- environmental research fund levies;

Supra note 2, s. 2.

Ibid., s. 14(2).

Communication from Mimi Fortier, Director, Northern Oil and Gas Directorate, DIAND (August 1999).

CPRA, supra note 2, s. 14(3).

See, for example, Terms and Conditions of the 2001 Beaufort Sea \& Mackenzie Delta Call for Bids, online: DIAND <http://www.inac.gc.ca/oil/act/Cal/Beau2001/nom/term_e.html> (date accessed: 20 April 2001). 
- work requirement and deposit;

- rentals;

- allowable expenditures;

- conditions relating to the environment; and

- land claim requirements.

A call for bids is assessed on the basis of a single biddable criterion. To date this has been the dollar value of the work committed.

The CPRA also contains detailed provisions dealing with exploration and production rights. ${ }^{31}$ Under the CPRA regime, as in southern Canada, the right to explore for oil and gas short of drilling is not exclusive. The right to explore by drilling and the right to produce are exclusive and are granted by way of a succession of licences. An exploration licence confers the exclusive right to drill and test for oil and gas, to develop the lands that are subject to the licence, and to obtain a production licence, providing that a commercial discovery is established in accordance with the terms of the CPRA.

A significant discovery licence is an intermediate step toward a production licence. Significant discovery licences confer the right to explore for, and the exclusive right to drill and test for, oil and gas; the exclusive right to develop the lands which are subject to the licence; and the exclusive right, subject to compliance with the CPRA, to obtain a production licence. ${ }^{32}$

A significant discovery licence is not a requirement. It is issued if the National Energy Board ("NEB") declares, either on an application or on its own initiative, that the exploratory well or wells indicate a "significant discovery." A significant discovery is

a discovery indicated by the first well on a geological feature that demonstrates by flow testing the existence of hydrocarbons in that feature and, having regard to geological and engineering factors, suggests the existence of an accumulation of hydrocarbons that has potential for sustained production."

"Sustained production" is not defined.

The declaration of a significant discovery applies to all frontier lands for which it is reasonable to believe the significant discovery may extend. A significant discovery licence is granted only in respect of the lands covered by the declaration of significant discovery that are held under licence. Where the declaration extends to Crown reserve lands, the minister may offer these lands in a call for bids, select a bid, and grant a significant discovery licence to the successful bidder. 
A production licence will be issued to an interest holder where the NEB declares that the significant discovery amounts to a commercial discovery. A "commercial discovery" is defined as "a discovery of petroleum that has been demonstrated to contain petroleum reserves that justify the investment of capital and effort to bring the discovery to production." 34 As with a significant discovery, the declaration of a commercial discovery applies to all frontier lands to which the commercial discovery may be reasonably believed to extend. Again, if the commercial discovery extends beyond lands held under licence to other Crown reserve lands, the minister may grant a production licence through a call for bids process.

As in the south, the acquisition of oil and gas rights does not automatically confer the right to carry out the activities necessary to explore for and produce oil and gas. The COGOA establishes a scheme for licensing and authorizing any work or activity proposed to be carried on relating to the exploration for, or the production of, oil or gas. In addition, the $C O G O A$ provides for the conservation of resources and regulates the protection of the environment and the safety of workers. The NEB is the primary administrator of the regulatory provisions of the COGOA.

Prior to authorizing any work or activity, the NEB requires the submission of a benefits plan for the benefit of Canadians. Typically, DIAND will make a benefits plan a condition of a call for bids. Under the $C O G O A$, a benefits plan is defined as

a plan for the employment of Canadians and for providing Canadian manufacturers, consultants, contractors and service companies with a full and fair opportunity to participate on a competitive basis in the supply of goods and services used in any proposed work or activity referred to in the benefits plan. ${ }^{35}$

A benefits plan may also include provisions to ensure that disadvantaged individuals or groups have access to training and employment opportunities, and to ensure that such groups are able to participate in the supply of goods and services. ${ }^{36}$ Under the $C P R A / C O G O A$ regime a benefits plan is not required to be structured as a form of contract. However, development of and adherence to a benefits plan is made a condition of an oil and gas disposition.

The NEB cannot approve a development or authorize any work or activity until the minister has approved or waived the requirement for approval of a benefits plan. ${ }^{37} \mathrm{As}$ discussed below, where the Crown grants oil and gas rights over s.7(1)(b) lands where the Inuvialuit own the surface, the developer is required under the IFA to negotiate an access agreement with the Inuvialuit. This may include a number of provisions including equity participation or other similar types of participatory benefits. ${ }^{38}$ Where this is the case, the

$\begin{array}{ll}34 & \text { Ibid. } \\ 3 & \text { Supra note } 3, \text { s. } 5.2(1) . \\ 36 & \text { Ibid., s. } 5.2(3) . \\ 37 & \text { Ibid., s. } 5.2(2) . \\ 38 & \text { IFA, supra note } 6, \text { s. } 10(3) \text {. }\end{array}$


practice of the minister has been to waive the requirement for a separate COGOA/CPRA benefits plan.

There are also provisions under the IFA that apply to Crown surface and subsurface land. Section $16(11)$ of the IFA provides that general guidelines developed by governments relating to social and economic interests, including employment, education, training, and business opportunities to favour natives shall be considered and applied as reasonably as possible to each application for exploration, development or production rights. Section 16(11) also applies to s. 7(1)(b) lands.

\section{b. Inuvialuit Oil and Gas Rights and Operations}

The issuance of oil and gas rights between the Inuvialuit and a private developer is a matter of private contract. Disposition of subsurface interests is administered by the Inuvialuit Land Administration (the "ILA"), a division of the Inuvialuit Regional Corporation, under the IFA and the Inuvialuit Land Administration Rules and Procedures. ${ }^{39}$ The ILA Rules and Procedures provide that dispositions of oil and gas interests must be made by way of a Concession Agreement, ${ }^{40}$ which must occur through a bidding process. ${ }^{41}$ The ILA Rules and Procedures do not specify the form of a Concession Agreement.

The COGOA continues to apply to oil and gas operations on Inuvialuit lands. Where the Inuvialuit dispose of oil and gas rights, the ILA may set terms and conditions with respect to the environment and safety that equal or exceed the standards provided for under the $C O G O A .^{42}$

\section{LAND USE}

The regulatory regime governing the use of land in the Inuvialuit Settlement Region is primarily a function of ownership.

\section{a. Crown Lands}

Land use permits and other tenures over Crown-owned land are administered by DIAND under the Territorial Lands $A c t{ }^{43}$ Temporary land use permits are issued under the Territorial Land Use Regulations. ${ }^{44}$ Before these can be issued, the application must go through an environmental assessment under the Canadian Environmental Assessment

IFA, supra note 6, s. 6(1)(a); Inuvialuit Land Adminstration Rules and Procedures (Inuvik: Inuvialuit Implementation Committee, 1985) [hereinafter ILA Rules and Procedures]. ILA Rules and Procedures, ibid., s. 6(2)(k).

Ibid., s. 12(1).

IFA, supra note 6, s. 7(99).

R.S.C. 1985, c. T-6 [hereinafter $T L A$ ].

C.R.C., c. 1524 [hereinafter TLUR]. 
Act..$^{45}$ Temporary land use applications must also go through the environmental assessment process under the IFA. ${ }^{46}$ The IFA environmental assessment process is discussed below. A detailed discussion of CEAA is beyond the scope of this article.

The sale and lease of Crown lands is provided for under the Territorial Land Regulations. ${ }^{47}$ Any sale of more than 160 acres or any lease of more than 640 acres must be approved by the federal cabinet. ${ }^{48}$ The federal cabinet is also authorized to issue rights-of-ways and other long-term tenures for transmission corridors, roadways, and other activities connected with a pipeline. ${ }^{49}$ It is not clear whether these actions would constitute a "licence or approval ... that would have the effect of permitting any proposed development to proceed" such as to trigger the requirements of the IFA environmental assessment process. ${ }^{50}$ They do not have to go through a CEAA process. However, it is likely that any project that required this form of tenure would trigger these requirements through some other aspect of the project.

\section{b. Inuvialuit Lands}

Surface tenures over Inuvialuit-owned lands are administered by the ILA under the IFA and the ILA Rules and Procedures. ${ }^{\text {sI }}$ The IFA provides that if commercial access is required to Inuvialuit lands for a permanent right-of-way to reach non-Inuvialuit lands, or to exercise interests on Inuvialuit lands, this is subject to the negotiation of a Participation Agreement under s. 10 of the IFA. ${ }^{52}$ However, s. 10 of the IFA provides that a developer must have concluded a valid Participation Agreement "except as otherwise agreed" by the ILA. ${ }^{53}$ Therefore, it appears that a developer who wishes to access Inuvialuit lands can either enter into a Participation Agreement, or the ILA must be satisfied that the objectives of these provisions have been met in some other way.

This interpretation appears to be supported by the ILA Rules and Procedures. These rules provide that "where the Applicant has been issued ... all Rights required for his activities, the Administrator shall agree to waive the requirement of the conclusion of a Participation Agreement." ${ }^{\text {"S }}$ Thus it appears that the IFA are free to negotiate either some form of Participation Agreement or to obtain some other commensurate benefit prior to Inuvialuit lands being used in connection with commercial activities.

S.C. 1992, c. 37 [hereinafter CEAA]. See Law List Regulations, SOR/94-636, Schedule I, Part 1I, s. 31; and Inclusion List Regulations, SOR/94-637, s. 70. Note, the IFA expressly provides that nothing in it restricts the power or obligation of the federal government to carry out an environmental impact and review under the laws and policies of Canada: supra note 6, s. 11(32).

TLUR, supra note 44, ss. 22-23; IFA, ibid., s. II(31).

C.R.C., c. 1525 [hereinafter $T L R$ ].

$T L A$, supra note 43, s. 11.

lbid., ss. 8, 23(f).

IFA, supra note 6, s. II(31).

Ibid., s. 6(1)(a).

Ibid., ss. 7(18)(c)-(d).

Ibid., s. 10(2).

Supra note 39 , s. 16(6)(a). 
A Participation Agreement may include the appropriate rent for the land in question and terms and conditions respecting the nature and magnitude of the land use. These terms and conditions may include:

- costs associated with any inspection of the development site;

- wildlife compensation, restoration, and mitigation;

- employment, service, and supply contracts;

- education and training; and

- equity participation or other similar types of participatory benefits. ${ }^{55}$

The process for negotiating a Participation Agreement may be agreed to in advance by the developer and the ILA under a Cooperation Agreement. ${ }^{56}$ In the absence of such an agreement, the government of Canada may determine procedures and timetables for concluding a Participation Agreement after negotiating with the ILA. ${ }^{57}$ The negotiation of a Participation Agreement may involve significant internal consultations with other Inuvialuit organizations.

Subsurface interest holders on Inuvialuit lands have a guaranteed right of access under certain conditions. ${ }^{58}$ If the developer and the ILA are unable to agree on a Participation Agreement, the issue may go to arbitration. ${ }^{59}$ The Arbitration Board is made up of appointees of the government of Canada (with input from the Inuvialuit, industry, and the governments of the Northwest Territories and Yukon), the Inuvialuit, and industry. ${ }^{60}$ The Arbitration Board may accept either of the parties' last proposals or, after consultation with the parties, make a compromise ruling. ${ }^{61}$

It is likely that whatever use the Inuvialuit lands would be put to would also be subject to the IFA environmental assessment process.

\section{WATER RIGHTS AND THE DEPOSIT OF WASTE}

The use of water and the deposit of waste in the Inuvialuit Settlement Region are regulated by the Northwest Territories Water Board ("NWTWB") under the Northwest Territories Waters $A \mathrm{At}^{62}$ and the Northwest Territories Waters Regulations. ${ }^{63}$ The

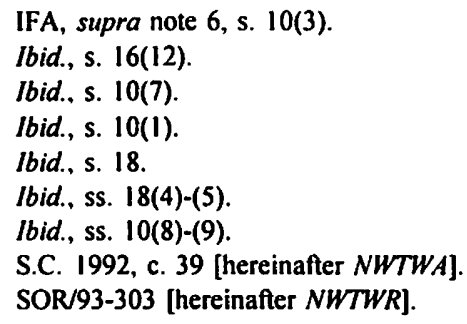


NWTWB is composed of four to nine members appointed by the Minister of Indian and Northern Affairs. ${ }^{64}$ Three of these members are nominees of the GNWT ${ }^{65}$

Depending on the amount of water that a project requires and other aspects of the project, such as watercourse crossings, a proponent may need either a "type A licence" or a "type B licence." licence unless the applicant consents to the disposition of the application without such a hearing and no one else requests one. ${ }^{67} \mathrm{~A}$ type $\mathrm{A}$ licence may only be issued with the approval of the Minister of Indian Affairs and Northern Development. ${ }^{68}$ The NWTWB may hold a public hearing with respect to a type $B$ licence if it believes that this hearing is in the public interest. ${ }^{69}$ If it does, it must also obtain the approval of the minister before issuing the licence. ${ }^{70}$

The NWTWB is required to go through a $C E A A$ process before granting any licences. ${ }^{71}$ Most applications to the NWTWB would also have to go through the IFA environmental assessment process. ${ }^{72}$

\section{THE IFA ENVIRONMENTAL ASSESSMENT PROCESS}

As indicated above, there are two environmental assessment processes in the Inuvialuit Settlement Region: that stipulated within $C E A A$, and that established under the IFA. The IFA process applies to certain "developments" in the Inuvialuit Settlement Region. "Developments" are broadly defined and could incorporate virtually any commercial or industrial undertaking. ${ }^{73}$ The IFA environmental assessment process consists of two stages: a screening and, if necessary, an environmental review. No licences or approvals can be issued until these requirements have been met. ${ }^{74}$

The screening is conducted by a body known as the Environmental Impact Screening Committee (the "Screening Committee"). ${ }^{75}$ Following the submission of information by the proponent, the Screening Committee determines whether the proposed development could have a "significant negative environmental impact." Based on this assessment, the Screening Committee suggests to the appropriate government authority whether, in its

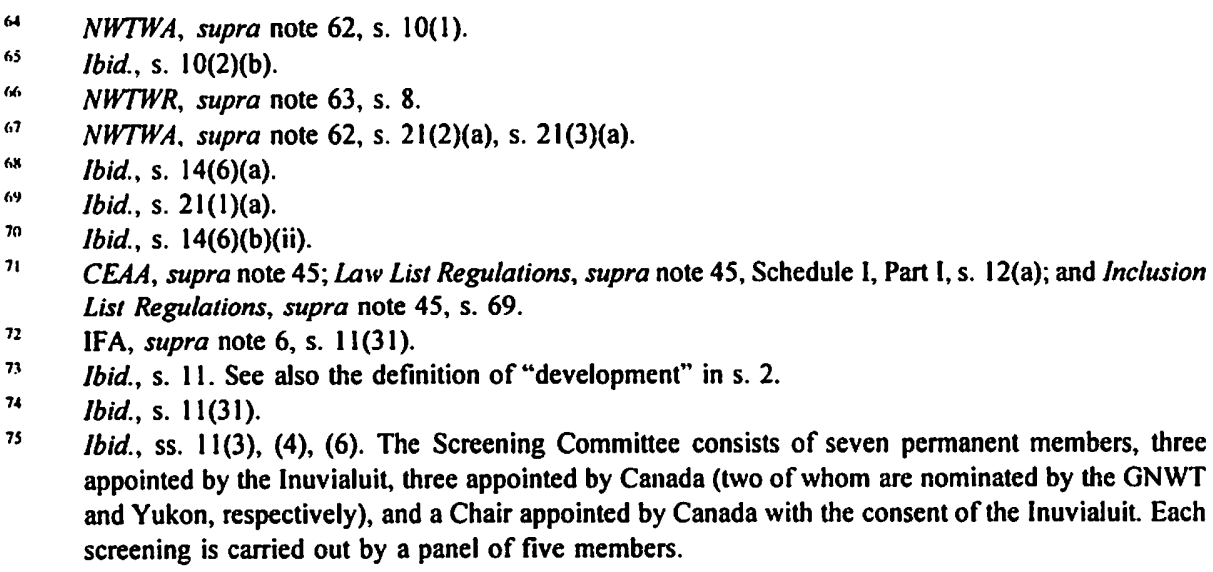


view, the development should proceed without further review, undergo further environmental assessment, or be rejected. ${ }^{76}$

If the Screening Committee determines that the development should undergo a further review, and the project is subject to a governmental development or environmental impact review process that the Screening Committee believes adequately encompasses the assessment and review function, it will refer the proposal to the body carrying out that review. ${ }^{77}$ Alternatively, if the Screening Committee does not believe that the review process will adequately encompass that function, or the review body declines to do so, the Screening Committee will refer the proposal to a body known as the Environmental Impact Review Board (the "Review Board") for a public review. ${ }^{78}$ The Review Board must review all projects referred to it and then must recommend whether the development should proceed and, if so, on what terms and conditions. The Review Board can also recommend that the development should be subject to further assessment and request the information needed for this purpose. ${ }^{79}$

The IFA environmental assessment process is advisory. If the Review Board makes a recommendation to a government authority, that authority can make its own determination whether the project can proceed and, if so, on what conditions. ${ }^{80}$ However, if it does not accept the Review Board's recommendations, it must give written reasons for this and must make these reasons public. ${ }^{81}$

A similar process is provided with respect to wildlife under s. 13 of the IFA.

\title{
D. The Mackenzie Valley ${ }^{82}$
}

The Gwich'in and Sahtu Agreements provided for the replacement of a significant portion of the pre-existing land and water management regime in the Mackenzie Valley with an integrated system of land and water management. Consequently, three main components to the legal regime in the Mackenzie Valley will apply to most upstream oil and gas developments: the regime in relation to oil and gas rights and operations; the requirements for access to land; and the process for land and water use approvals. Each of these components is discussed below.

\section{OIL AND GAS}

\section{a. Crown Oil and Gas Rights and Oil and Gas Operations on Crown Lands}

As discussed above, Crown oil and gas interests in the Mackenzie Valley continue to be administered under the CPRA. However, the GFA and SFA have had some effect on

\author{
Ibid., s. II(13). \\ Ibid., s. 11(15). \\ Ibid., ss. $11(16),(18)$. \\ Ibid., s. 11(24). \\ Ibid., s. 11(27). \\ Ibid., ss. 11(29), (30). \\ As defined in the MVRMA, supra note 21 .
}


the CPRA regime. Prior to calling for nominations or bids in the Gwich'in or Sahtu Settlement Areas, DIAND is required to notify the Gwich'in or Sahtu, as appropriate, and to provide them with an opportunity to present their views on the matter. Areas of concern include benefits plans and other terms and conditions to be attached to the rights issuance. DIAND is then required to consider these views. ${ }^{83}$ This requirement expands the legal requirement of DIAND under the CPRA and elevates it to a constitutionally protected legal requirement.

In addition, the GFA and SFA both impose express requirements for consultation on a person involved in oil and gas activity in these settlement areas. ${ }^{84}$ In general, the scope of this consultation may include:

- environmental impact and mitigation measures;

- impact on wildlife harvesting and mitigation measures;

- location of camps and other site specific concerns;

- maintenance of public order, including liquor and drug control;

- employment, business opportunities and contracts, training, orientation and counselling, working conditions, and terms of employment;

- expansion or termination of activities;

- $\quad$ processes for future consultations; and

- other matters of importance to the Gwich'in and Sahtu, as appropriate, or to the person engaging in the activity.

It is important to note that these requirements differ from the common law requirement to consult established through the case law dealing with aboriginal and treaty rights. The GFA and SFA obligations to consult apply regardless of whether there is any risk of infringing treaty rights. The GFA and SFA also provide much greater detail about the scope and content of this consultation than does the common law. ${ }^{85}$

GFA, supra note 13, c. 21.1.2; SFA, supra note 13, c. 22.1.2.

GFA, ibid., c. 21; SFA, ibid., c. 22.

There have been no cases to date arising directly out of the requirements for consultation contained in the Settlement Agreements. One case does deal with the issue of a consultation with a Yukon First Nation which concluded a land claim settlement agreement. In Vuntut Gwich'in First Nation v. Canada (Minister of Indian and Northern Affairs). [1999] I C.N.L.R. 299 (F.C.T.D.), aff d [1999] 1 C.N.L.R. 306, (F.C.A.), leave to appeal to S.C.C. refused [1998] S.C.C.A. No. 398, online QL (SCCA), the First Nation sought an order setting aside the decision of the Minister of Indian and Northern Affairs to grant a land use permit to permit extended flow tests on three wells in the Eagle Plains area of the Yukon. While it is not clear from the reasons of the trial judge whether the First Nation argued that they had a constitutional right to consultation, or simply that the permit process was flawed because their right to be heard had been denied, the case confirms that statements by courts to the effect that a First Nation cannot succeed in challenging the adequacy of consultation 
Oil and gas operations on Crown lands in the Mackenzie Valley continue to be administered by the NEB under the $C O G O A$. These provisions, including the requirement for benefits agreements, have been discussed above.

As considered above, under the COGOA, the NEB cannot approve a development or authorize any work or activity until the minister has approved or waived the requirement of a benefits plan. ${ }^{86}$ Like the situation under the IFA where the Crown grants oil and gas rights over either Gwich' in or Sahtu Surface Only lands, the developer is required under the GFA or SFA, respectively, to negotiate an access agreement to obtain access to these lands. This is discussed further below. Where this agreement satisfies the requirements under the $C O G O A$, the practice of the minister has been to waive the requirement for a separate $C O G O A / C P R A$ benefits plan. ${ }^{87}$

\section{b. Gwich'in and Sahtu Oil and Gas Interests}

Oil and gas rights on Surface or Subsurface lands are administered by the Gwich'in and the Sahtu pursuant to their land claim agreements. Rights to explore for oil and gas on these lands are a matter of private law to be negotiated directly with the First Nation.

No formal framework currently exists in either the Gwich'in or Sahtu settlement areas for the issuance and management of exploration and production rights on Surface or Subsurface lands. Similarly, there are also no provisions in place to harmonize rights within reservoirs that cross boundaries between Crown and Gwich'in/Sahtu-owned oil and gas resources.

The COGOA also applies to these lands with respect to licensing of specific activities and to safety and environmental standards.

\section{ACCESS TO LAND}

A significant oil and gas development will generally require a long-term interest in land. On Crown-owned lands in the Mackenzie Valley, these interests continue to be granted under the $T L R$. Significantly, however, a proponent must obtain a land use permit to carry out a particular activity on these lands.

If a developer requires access to Gwich' in or Sahtu-owned surface lands, either for the purpose of conducting activities on these lands or for securing access across these lands to conduct activities on Crown-owned lands, it must deal with the appropriate body under the respective settlement agreements.

where they failed or refused to take advantage of opportunities provided to them, are equally applicable in the context of settled claims.

Supra note 3, s. 5.2(2).

n) For example, the benefits plan developed by Ranger Oil Ltd. for the Tulita and Norman Wells area in accordance with Article 22.2 of the SFA was accepted by the minister for the purposes of the requirement under the $C O G O A$. 
In the Gwich' in settlement area an "Access Authorization"88 from the Gwich'in Land Administration will be required in order to access Gwich'in private lands. ${ }^{89}$ Similarly, in the Sahtu settlement area authorization from the appropriate district land corporation will be required to access Sahtu private lands. ${ }^{90}$ Typically, access agreements may be expected to incorporate specific terms and conditions for access, such as routing, siting, and timing provisions in addition to compensation provisions. In effect, the access agreements are a type of community benefits plan or agreement.

Persons having a right to explore, develop or produce oil and gas under Gwich'in or Sahtu settlement lands have the right to obtain access to these lands, subject to certain conditions. ${ }^{91}$ In the event that the parties are unable to negotiate an agreement in respect of surface access under the GFA and SFA, the dispute is to go to a Surface Rights Board. These boards have not yet been set up; in the interim, disputes over access to surface lands for the purpose of exploring for, or exploiting, oil or gas will go to arbitration.

Again, notwithstanding the negotiation of an Access Authorization, as with Crown lands, the proponent must also obtain permission from the relevant Land and Water Board before being allowed to use these lands.

\section{LAND AND WATER MANAGEMENT}

As discussed, the GFA and SFA required that an integrated system of land and water management be implemented in the Mackenzie Valley. This was accomplished under the MVRMA.

The following discussion provides a brief review of the $M V R M A$ followed by a consideration of the land water use and application process under this regime. The discussion concludes with a review of the environmental assessment process under the MVRMA.

\section{a. The MVRMA}

The $M V R M A$ consists of a number of different parts. Part 1 sets out general provisions regarding the various boards established under the $A c t$. The overriding purpose of the establishment of these boards is "to enable residents of the Mackenzie Valley to participate in the management of its resources for the benefit of the residents and of other Canadians." These boards are established as independent institutions, and their actions are subject to judicial review. ${ }^{92}$

GSA Water License \& Land Use Permit Application Process (Gwich'in Land and Water Board) at 2, online: Gwich'in Land and Water Board <http://ww.glwb.com/guide3/pdf> (last accessed: 29 June 2001).

GFA, supra note 13 , c. 20.4.4, c. 20.4.6.

Deline Land Corporation; Tulita District Land Corporation Ltd.; K'ahsho Got'ine Lands Corporation Lid. (Fort Good Hope area). See also SFA, supra note 13, c. 21.4.4, c. 21.4.6.

GFA, supra note 13, c. 20.4.6; SFA, ibid., c. 21.4.6.

MVRMA, supra note 21 , s. 32. 
Part 2 of the MVRMA establishes land use planning boards in each of the Gwich'in and Sahtu settlement areas and sets out general provisions with respect to the preparation of, and compliance with, land use plans. The Gwich'in and Sahtu Land Use Planning Boards are responsible for developing a land use plan in respect of all lands within their respective settlement areas: Crown, settlement, and private lands. ${ }^{93}$

The purpose of the land use planning process is to protect and promote the social, cultural, and economic well-being of residents and communities in the respective settlement areas, having regard to the interests of all Canadians. ${ }^{94}$ Having said this, special attention must be devoted in the preparation of these plans to the rights of the Gwich' in and Sahtu under their land claim agreements. ${ }^{95}$

The preparation of a land use plan by the Gwich'in and Sahtu Land Use Planning Boards must involve the participation of the respective First Nations and of residents and communities in the settlement areas. ${ }^{96}$ These plans must also address the use of water within the settlement areas. The Gwich'in Land Use Plan has been approved by the Gwich'in and the territorial minister responsible for this portion of the Act and awaits approval by the Minister of Indian Affairs and Northern Development. The Sahtu Land Use Plan is still under preparation.

Once a land use plan has been approved, all proposed activities in respect of those lands must fall within a use as contemplated by the plan and must be conducted in accordance with the plan. ${ }^{97}$ The plans apply to First Nations organizations and to federal and territorial governments and their agencies.

Part 3 of the MVRMA establishes the Gwich'in and Sahtu Land and Water Boards and sets out the general scheme of land and water management under the Act. Part 4 establishes the Mackenzie Valley Land and Water Board ("MVLWB") and extends the land and water management system under Part 3 to the rest of the Mackenzie Valley. Except within municipal or local government boundaries, the responsible Land and Water Boards have the jurisdiction to issue all land and water use approvals. ${ }^{98}$ For activities wholly within the Gwich'in or Sahtu settlement areas, the respective Gwich' in and Sahtu Land and Water Boards are responsible for approval of land or water use. For all other activities, the MVLWB will be the responsible board and it will refer issues to the regional boards as necessary. ${ }^{99}$

In unsettled claim areas in the Mackenzie Valley, the MVLWB will screen applications and strike a panel to assess the application with representation on the panel from affected communities. The MVLWB will also deal with applications in respect of activities that physically extend through more than one settled area or from a settled area into an

Ibid., s. 41.

lbid., s. 35(a).

Ibid., s. 35(b).

lbid., s. 35(c).

Ibid., s. 46.

lbid., ss. 59-60.

See generally, Part III \& Part IV of MVRMA, supra note 21. 
unsettled area. In those cases, it will screen the application and then establish a panel with representation from the appropriate regional boards (e.g., the Gwich' in and/or Sahtu Land and Water Board) and affected communities in unsettled areas. ${ }^{100}$

Part 5 of the $M V R M A$ sets out the environmental assessment process in the Mackenzie Valley. This is discussed below. Part 6 provides for ongoing environmental monitoring and audit requirements. Part 7 provides for certain transitional provisions and consequential amendments. The provisions of Part 6 and 7 are beyond the scope of this article.

\section{b. Applications for Land and Water Use Permits}

An oil and gas company wishing to use certain lands must apply to the appropriate Land and Water Board for the relevant approvals. The Gwich'in, Sahtu, and Mackenzie Valley Land and Water Boards have established rules and procedures relating to land use permits and water use licences. In respect of land and water use, applications for oil and gas related activities may be expected to fall within one of three categories: no permit required, Type A permit (land) or licence (water) required, or Type B permit (land) or licence (water) required. The Mackenzie Valley Land Use Regulations establish which activities require a land use permit and which type of permit is required. ${ }^{101}$ The Northwest Territories Waters Regulations establish which activities require a water use licence. ${ }^{102}$

Most oil and gas related activities would likely require a Type A or Type B permit. The triggers for those approvals depend on the need for new cut lines or trails, the proposed construction or use of buildings, structures, camps, airstrips, fuel and supply storage sites, waste disposal sites, surface area of land required for the activity, and persons to be actively involved in the activity, among other things.

The MVRMA and MVLUR set out certain further requirements before the relevant Land and Water Board may issue a permit or licence. The most significant of these is that the applicant must obtain the permission of the landowner to use the land in question (i.e., the MVLWB is not a surface rights tribunal). ${ }^{103}$

The other requirements reflect the core regulatory regime established under the MVRMA. These are:

- that the proposed use of land is in accordance with an applicable land use plan. This is determined by the appropriate land use planning board. ${ }^{104}$ To the extent that a proposed use is non-conforming, and where the land use plan authorizes

Ibid., Part IV.

Mackenzie Valley Land Use Regulations, SOR/98-429 [hereinafter MVLUR].

Supra note 63.

Supra note 101, s. 18. While the words of the regulation could be clearer, this certainly appears to be the intent and is consistent with the way that they are interpreted by the MVLWB.

114

MVRMA, supra note 21 , ss. $46,47,61$. 
the land use board to consider exceptions to the plan, the proponent can apply for an exemption or for an amendment to the plan. ${ }^{105}$

- that the environmental assessment provisions of the $A c t$ have been complied with. ${ }^{106}$ These provisions are discussed further below.

- providing the application to the owner of the land in question and the appropriate departments and agencies of the federal and territorial governments, and notifying the affected communities and First Nations of the application to allow them to make representations. ${ }^{107}$

- $\quad$ seeking advice from First Nations and government with respect to heritage resources and the appropriate renewable resources boards established under the land claims agreements with respect to wildlife resources. ${ }^{108}$

The Land and Water Boards will require and consider traditional ecological knowledge in the process of considering applications. The boards consider that traditional ecological knowledge is separate and distinct from scientific information, which they will also consider. While there is some debate about the scope and content of traditional ecological knowledge, it is very generally defined as the knowledge that is typically held by the elders of a First Nation community and that relates to that community's relationship with, and use of, the land and resources.

Where a use of land is likely to have an impact in an area outside the Mackenzie Valley, the Mackenzie Valley Land and Water Board has the authority, with the minister's approval, to hold joint hearings or to enter into agreements with other regulatory agencies to co-ordinate activities and to avoid duplication. ${ }^{109}$

An application for a water use permit follows the same general process as a land use permit. The MVRMA does not replace the NWTWA or the NWTWR. It simply modifies these to the extent that they do not conform to the respective land claim agreements. It also replaces the NWTWB with the appropriate Land and Water Board under the MVRMA. Notwithstanding that some of the provisions that previously were in the NWTWA are now in the MVRMA, the process remains the same. In particular, the relevant Land and Water

Ibid., s. 48. It is interesting to note that while a person making an application to a Mackenzie Valley Board may wish to have its application pre-screened by the responsible land use planning board for conformity with the applicable land use plan, there is no specific provision for this in the legislation. However, First Nations, government or issuing bodies, and persons "directly affected" by a proposed activity may apply to the board for a determination of whether the activity complies with the applicable land use plan. An applicant or potential applicant could apply for a review and argue that they are directly affected, or an applicant could ask the board or other decision-maker to whom the application is to be made to refer the application.

Ibid., s. 62.

Ibid., s. 63.

Ibid., s. 64.

Ibid., s. 107. 
Board is generally still required to hold a public hearing in respect of a type A licence, and still requires the minister's consent before issuing such a licence. ${ }^{110}$

The most significant change to the $N W T W A$ regime is the addition of requirements that must be met under the $M V R M A$ before a water use permit can be issued. Many of the provisions of the $M V R M A$ that were discussed with respect to land use permits also apply to water use permits. In particular, applications for water use permits must be consistent with land use plans, must comply with the environmental assessment provisions of the $M V R M A$, and must be referred to various parties for input."

The MVRMA also adds further provisions in order to protect the Gwich'in's and Sahtu's water rights under their respective land claim agreements. These provisions may, in the appropriate circumstances, require a developer and the respective First Nation to enter into a Compensation Agreement with respect to the effects of a proposed development on the Gwich'in's and Sahtu's water rights. ${ }^{12}$ If these conditions are satisfied, the Land and Water Board may issue the permit or licence in question, which may include certain conditions. ${ }^{113}$ Before finalizing any conditions with respect to the protection of the environment, the Land and Water Board must consult with the territorial minister, the appropriate federal minister, or the owner of the land, as appropriate..$^{14}$

Under the $M V R M A$ "consult" is defined as providing the following:

- to the party to be consulted, notice of a matter to be decided in sufficient form and detail to allow that party to prepare its views on the matter;

- a reasonable period of time for the party to prepare those views;

- an opportunity to present those views to the party obliged to consult; and

- full and impartial consideration of any views presented.

This definition provides the minimum standard for consultation in respect of the actions and activities to which it applies. The definition is sufficiently broad and flexible that determining the specific scope of consultation will depend on the activity in question and on its location. The Land and Water Board must also include any conditions recommended by the environmental assessment process before issuing its final approval. ${ }^{115}$

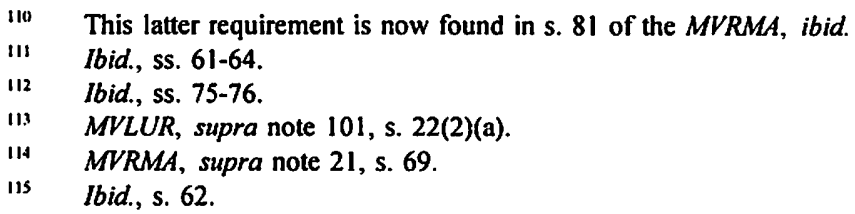




\section{c. Environmental Assessment}

Part 5 of the MVRMA establishes the primary environmental assessment process for the Mackenzie Valley. A Land and Water Board may not issue a permit or other authorization until this process is completed. ${ }^{116}$ The environmental review and assessment of a project under the MVRMA may include one or more of a "preliminary screening," an "environmental assessment," and an "environmental impact review."

A preliminary screening is necessary if a project requires an approval as identified in the Preliminary Screening Requirement Regulations. ${ }^{117}$ In turn, a project may be exempted from a preliminary screening under the Exemption List Regulations. ${ }^{118}$ Each regulatory authority (i.e., the authority responsible for issuing the licence, permit, or authorization for a project) is required to conduct a preliminary screening. ${ }^{119}$ A large number of regulatory authorities are usually involved in a major project; these authorities must cooperate in carrying out this preliminary screening. Where one of these authorities is the MVLWB, the others need not conduct a preliminary screening. ${ }^{120}$

This preliminary screening involves an initial examination of the proposal to determine if the development "might have a significant adverse effect on the environment" or "might be a cause of public concern." 121 Where the regulatory authorities determine that the development meets one or both of these tests, they must refer the proposal to the Mackenzie Valley Environmental Impact Review Board (the "Review Board") ${ }^{122}$ for an environmental assessment. ${ }^{123}$

An environmental assessment must include consideration of the factors set out in $\mathbf{s}$. $117(2)$ of the MVRMA. Following the environmental assessment, several options are open:

- If the Review Board believes that the development is not likely to have a significant adverse effect on the environment or is not likely to be a cause of significant public concern, it shall determine that an environmental impact review of the proposal need not be conducted. ${ }^{124}$

- If the Review Board believes that the development is likely to have such an impact, it may order that an environmental impact review take place or may recommend approval of the project subject to such conditions as are necessary to prevent this impact. ${ }^{125}$

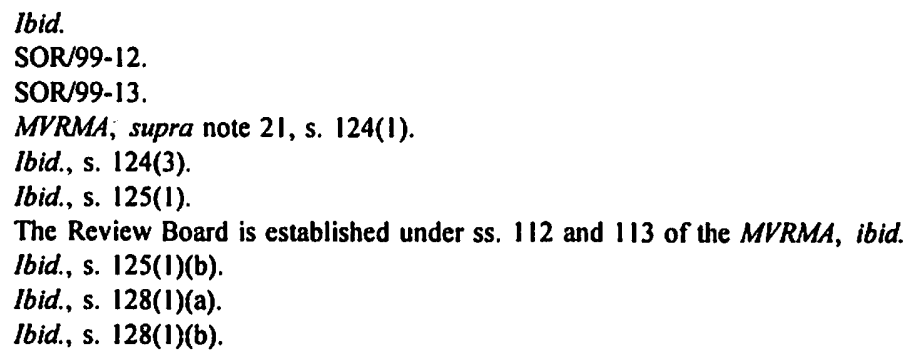


- If the Review Board believes that the development is likely to be a cause of significant public concern, regardless of the potential environmental impact, it shall refer the proposal for an environmental impact assessment. ${ }^{126}$

- Finally, where the Review Board believes that the development is likely to cause an adverse impact on the environment so significant that it cannot be justified, it may recommend that the project be rejected. ${ }^{127}$

The Review Board's report must be submitted to the Minister of Indian Affairs and Northern Development and to every other federal or territorial minister who has jurisdiction in relation to the development. ${ }^{128}$ Generally, the ministers may either accept or reject the Review Board's recommendations, or they may modify the recommendations in consultation with the board (with the exception of a recommendation that a project be referred for an environmental impact review based on public concerns). ${ }^{129}$ Irrespective of the Review Board's determination, the ministers may refer the proposal to the Federal Minister of the Environment for the purpose of a joint review under $C E A A$ if they determine that it is in the national interest to do so. ${ }^{130}$ The Review Board's report must also be submitted to any "designated regulatory agency" ("DRA") from which an authorization is required for the project. ${ }^{131}$ Currently, the NEB is the only DRA under the $M V R M A$.

Unless a project is referred for a joint review or some other form of cooperative review is undertaken, an environmental impact review is conducted by a review panel of at least three members appointed by the Review Board. ${ }^{132}$ The environmental impact review must consider the same factors as did the original environmental assessment, as well as considering certain additional factors. ${ }^{133}$ Specific components of the review process include public consultations or hearings in communities that would be affected by the development. $^{134}$

A review panel must issue a report containing the recommendation that the development should be approved (with or without mitigative or remedial measures or a follow-up program) or rejected. ${ }^{135}$ The report of the review panel must be submitted to the Minister of Indian Affairs and Northern Development and each responsible minister for consideration. ${ }^{136}$ The report must also be submitted to the NEB, if appropriate. ${ }^{137}$

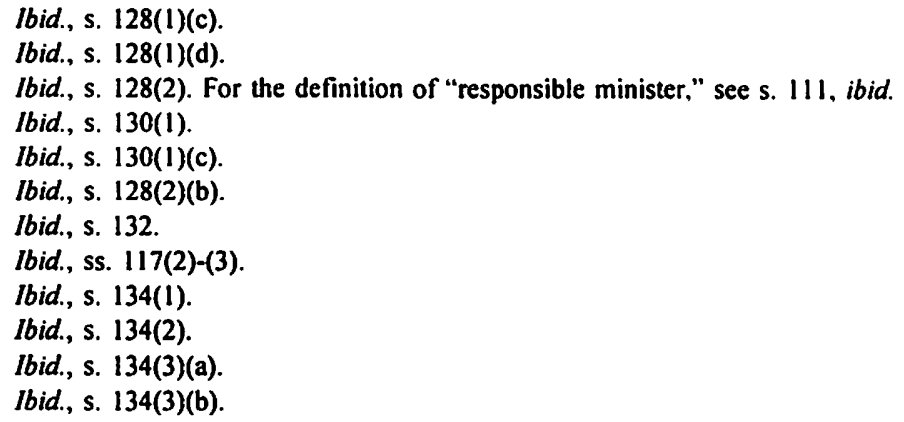


A final decision regarding the project rests with the Minister of Indian Affairs and Northern Development and with the other responsible ministers. ${ }^{138}$ If the project is approved, the relevant responsible agencies must act in conformity with that decision to the extent that the are able to do so. ${ }^{139}$

The MVRMA establishes a broad scope for undertaking cooperative environmental assessments. As mentioned above, a joint review can be carried out under the $C E A A$ where the ministers decide this is in the national interest. ${ }^{140}$ In addition, the Review Board and the NEB can carry out a joint review where the NEB is required to exercise authority with respect to the project. ${ }^{141}$ Where it appears to the Review Board that a project might have a significant adverse impact on the environment outside the Mackenzie Valley, the Review Board may, with the minister's approval, enter into an agreement with the appropriate authority to conduct a joint review. ${ }^{142}$ Finally, if part of a development is located in the Mackenzie Valley, and part is located in an adjacent region of the Northwest Territories, the Yukon or another province, the Review Board may agree with the Minister of the Environment, in respect of the $C E A A$, or with some other appropriate authority, to conduct a joint review of the proposal. ${ }^{143}$ In both of these situations, the joint review process stands in lieu of the requirements under the $M V R M A .{ }^{144}$

\section{THE YUKON}

\section{A. Development of The CURRent Regime}

As in the Northwest Territories, until relatively recently, Canada was the owner of, and had sole jurisdiction over, oil and gas resources in the Yukon. While the current regulatory regime that applies to oil and gas activity in the Yukon is, in part, the product of changes introduced through the settlement of land claims, the main differences between the developing regimes in the Yukon and the Northwest Territories are the result of the devolution of jurisdiction over oil and gas resources from Canada to the Yukon Territorial Government.

In 1993 Canada and the Yukon signed the Canada-Yukon Oil and Gas Accord. That agreement provides for the transfer of responsibility for oil and gas resources to the Yukon government following the period of time required to prepare appropriate legislation in consultation with Yukon First Nations and other stakeholders. On November 19, 1998, under the terms of the Canada-Yukon Oil and Gas Accord Implementation Act, this transfer of responsibility officially occurred. ${ }^{145}$

Ibid., s. 135.

Ibid., s. 136(2).

Ibid., s. 130(1)(c).

Ibid., s. 139.

Jbid., s. 140.

Ibid., s. 141.

Ibid., ss. 138(2), 139(3), 140(4).

S.C. 1998, c. $S$ [hereinafter Implementation Act]. 
The Yukon government's powers are set out in the Yukon Act. ${ }^{146}$ The Implementation Act amends the Yukon Act to define the scope of the Yukon's powers over oil and gas in the territory. The Yukon government has the power to make laws respecting exploration for oil and gas, development, conservation and management of oil and gas, and oil and gas pipelines other than extra-territorial pipelines. The Yukon also has other powers equivalent to those of provinces under s. 92A of the Constitution Act, $1867,{ }^{147}$ including the power to make laws respecting the export of primary production from oil and gas, and the power to make laws for direct and indirect taxation of oil and gas production.

The powers granted to the Yukon government apply throughout the Yukon (subject to the terms of land claim agreements and self-government agreements) and to certain waters in bays along the Beaufort Sea. In general, however, the Yukon's oil and gas powers do not extend into the offshore region.

Technically speaking, oil and gas resources in the Yukon (other than those under Category A Settlement Land, as discussed below) will continue to be owned by the federal Crown. However, under s. 47.1 of the Yukon Act, the federal government has the power to transfer the administration and control of oil and gas in federal Crown lands to the Yukon. This transfer occurred on the date that the Implementation Act took effect.

The Implementation Act also contains transitional measures protecting existing federal oil and gas dispositions. Existing federal dispositions remain in effect after the transfer date, but Yukon oil and gas laws apply to them. However, specified rights under the existing federal dispositions may not be diminished by Yukon oil and gas laws, and the term of the existing federal dispositions may not be reduced. Existing federal dispositions may be cancelled under Yukon oil and gas laws, but only if they could have been cancelled in similar circumstances under the applicable federal legislation. The Implementation Act requires that the Yukon maintain comparable provisions in its oil and gas legislation for as long as existing federal dispositions remain in existence.

As a result of these amendments to the Yukon Act, and as a result of the transfer of the interest in Crown lands in the Yukon to the control of the Yukon government, this government now, effectively, has provincial powers and responsibilities for oil and gas resources in the territory. The Yukon government has used these powers to enact the Yukon Oil and Gas Act, which now governs oil and gas exploration and development in the Yukon. ${ }^{148}$

It is important to know that the devolution of jurisdiction over oil and gas to the Yukon government was not accompanied by the devolution of jurisdiction over land management. The latter is not expected to occur until 2002. It is the combined effect of the settlement of land claims, the devolution of jurisdiction over oil and gas, and the retention by Canada, for the time being, of jurisdiction over land management which gives rise to the regulatory regime over oil and gas development in the Yukon.

\footnotetext{
R.S.C. 1985, c. Y-2.

(U.K.), 30 \& 31 Vict., c. 3, reprinted in R.S.C. 1985, App. II, No. 5.

S.Y. 1997, c. 16 [hereinafter YOGA].
} 
This should not be interpreted to suggest that the settlement of land claims has not had an effect on this legal framework. In the Yukon seven First Nations have concluded final agreements and self-government agreements: the Champagne and Aishihik First Nations, the Teslin Tlingit Council, the Vuntut Gwich'in First Nation, the First Nation of Nacho Nyak Dun, the Little Salmon/Carmacks First Nation, the Selkirk First Nation, and the Tr'ondek Hwech'in First Nation.

Each of these agreements has been brought into force under federal and Yukon legislation. ${ }^{149}$ In the Yukon each of the individual settlement agreements incorporates the Yukon First Nations Umbrella Final Agreement, ${ }^{150}$ the provisions of which apply throughout the Yukon, along with specific provisions that apply only to that Yukon First Nation, such as land selections, economic opportunities, and designation of protected areas.

Under the Umbrella Final Agreement the lands which are included within the individual Yukon First Nations' settlement agreements fall into three categories: Category A; Category B; and Fee Simple Settlement Land.

Yukon First Nations own the subsurface of Category A Settlement Land in fee simple, including oil and gas, and they hold all of the rights, obligations and liabilities "equivalent to fee simple ownership" for the surface of the land. ${ }^{\text {s1 }}$ Yukon First Nations own the surface only in Category B Settlement Lands. Fee Simple Settlement Lands are primarily found within communities where First Nations selected previously titled lands. The Yukon First Nations hold the fee simple title to the surface of these lands (collectively "Yukon Settlement Lands").

In addition to describing the Yukon First Nations' land tenure, the Umbrella Final Agreement provisions also require the federal and Yukon governments to establish development assessment, land use planning, water management, surface rights and wildlife management processes. These processes apply on and off Yukon Settlement Lands and provide for Yukon First Nation representation on these boards.

Finally, some claims by First Nations extend across provincial and territorial boundaries, and across the boundaries of other First Nation claims. ${ }^{152}$ Transboundary

Yukon First Nations Land Claims Settlement Act, S.C. 1994, c. 34; An Act Approving Yukon Land Claims Final Agreements, S.Y. 1993, c. 19.

1so DIAND, Umbrella Final Agreement Between the Government of Canada, the Council for Yukon Indians and the Government of the Yukon (Ottawa: DIAND, 1993) [hereinafter Umbrella Final Agreement].

151 The "equivalent to" qualification was included in order to allow Yukon First Nations to retain their aboriginal title to the surface of Category $A$ and $B$ Settlement Lands to the extent that aboriginal title can coexist with the land tenure rules in the final agreements.

152 For example, under Appendix C of the Gwich'in Final Agreement, concluded in 1992, the Tetlit Gwich'in from the Northwest Territories hold fee simple title to the surface of 600 square miles (1,554 square kilometres) of land in the Peel River region of the northeastern Yukon. Those lands are treated as though they were Category B Settlement Land for most of the purposes of the Umbrella Final Agreement. The Umbrella Final Agreement provisions respecting surface rights, development assessment, water management, and land use planning all apply to Gwich'in lands in 
agreements and provisions in land claim agreements will form an important part of the knowledge base for those interested in gaining access to oil and gas rights in the Yukon because they give rights, typically with respect to consultation and management of resources, to aboriginal groups that are outside the jurisdiction in which oil and gas activity is to take place.

\section{B. The CURRENT REgulatory REgime IN THE YUKON}

As a result of the devolution of authority over oil and gas in the Yukon, neither the $C P R A$ nor the COGOA applies to oil and gas dispositions or activity in the Yukon. The developing framework for the regulation of the oil and gas industry in the Yukon is based on the paradigm of a common regime. The common regime is established through $Y O G A,{ }^{153}$ and the laws of Yukon First Nations which $Y O G A$, may, in accordance with the YOGA and their powers of self-government, adopt provisions of the $Y O G A$ in respect of oil and gas resources falling within their Category A Settlement Lands. ${ }^{154}$ Regulations are being developed as required under the $Y O G A .{ }^{155}$ For an initial five-year term, the Oil and Gas Resources Branch of the Yukon Department of Economic Development will administer the YOGA and its regulations with assistance from the NEB.

It is intended that all oil and gas rights in the Yukon, whether issued by the Yukon government or by a Yukon First Nation for its Category A lands, will normally be issued after a competitive bid process. A four-step process will ordinarily be followed prior to issuing oil and gas rights. Those steps are: consultation on a government-to-government basis with First Nations in whose traditional territories the prospective disposition will take place; a call for nominations of prospective parcels of land; a review process to determine whether there are any concerns relating to the parcels nominated from an environmental, socio-economic, or surface access perspective; ${ }^{156}$ and a call for bids.

The first step is critical because the YOGA provides that oil and gas rights in the traditional territory of a First Nation may not be issued without the consent of that First Nation. The use of the phrase "traditional territory" broadens the scope of the area in which consultation will be required beyond merely Category A, Category B, or Fee Simple Settlement lands.

The Yukon has adopted a two stage rights management process similar to those in Alberta and British Columbia. Exploration permits will be issued which will grant the exclusive right to explore for oil and gas by drilling, and the rights granted will generally extend to the basement. Leases will be used to grant the exclusive right to produce oil or gas or both, and will generally only extend to areas and horizons which are productive or capable of being produced. The maximum depth will be the bottom of the deepest

the Yukon. The IFA also has provisions that extend into the Yukon

Supra note 148.

Ibid., s. 11(1) and Yukon First Nation Self-Government Agreements, s. 20.1.

Oil and gas disposition; draft geoscience exploration; draft drilling and production; draft licence administration; and draft royalty regulations.

1s6 Yukon government departments and agencies, First Nations in whose traditional territories the rights are expected to be issued, and the public may participate in the review. 
productive zone. While the initial term is five years, a lease will be renewed as long as the holder continues to demonstrate that the lands are capable of production.

The disposition regulations are intended to accommodate the fact that oil and gas prospects may extend through Settlement Lands to non-settlement lands or into neighbouring jurisdictions such as British Columbia and the Northwest Territories. Under the common regime in the Yukon, a single lease may extend across both Category $A$ and Category B lands if these regulations are adopted by a First Nation, eliminating an area for potential interjurisdictional issues to arise.

In the Yukon, under normal circumstances, no oil and gas activity valued at more than $\$ 1$ million per year can be carried out unless a benefits agreement is in effect. The parties to the benefits agreement are to be the licensee, the minister on behalf of the Yukon Territorial Government, and the Yukon First Nation on whose settlement land or traditional territory the oil and gas activity will be carried out. ${ }^{157}$ Benefits agreements must contain undertakings by the licensee to provide employment and training opportunities to First Nations, local community residents, and other Yukon residents, as well as opportunities to supply goods and services to the licensee and contractors of the licensee. ${ }^{158}$ As in the federal regime, a benefits agreement may be waived in some circumstances with the consent of the Yukon government and the First Nation. It is intended that the significance of the benefits in benefits agreements should be commensurate with the nature, scale, scope, and duration of the work. ${ }^{159}$ In addition, a benefits agreement may cover activities which are to be carried out under more than one licence.

In the Yukon, all oil and gas activities will be subject to environmental assessment prior to the granting of a licence. Assessments are supposed to be carried out under an interim Yukon Environmental Assessment Act ("YEAA") pending resolution of the development assessment process mandated under the Umbrella Final Agreement. However, the $Y E A A$ has not yet been passed. Accordingly, environmental assessments are currently carried out in accordance with the provisions of $C E A A$.

Under the YOGA, any person may enter onto and use the surface of land for the purpose of exercising rights held under an oil and gas disposition or licence, subject to obtaining the consent of persons having a right or interest in the surface lands. In respect of Settlement Lands, whether the lands are Category A or B settlement lands, the permission of the First Nation owner must generally be obtained. However, in specific circumstances identified in the Umbrella Final Agreement, and in the individual Final Agreements, permission is not necessary. Where the lands are Fee Simple Settlement Lands, the permission of the registered owner must be obtained. If the owner or interest holder is the Government of Canada or of the Yukon, express consent is not necessary. ${ }^{160}$

Ibid., s. 68.

Ibid., s. 68(3)(b).

lbid., s. 69. 
In the event that consent to access any lands in the Yukon is refused, an order for access may be sought from the Yukon Surface Rights Board ("YSRB"). The YSRB is established under the federal Yukon Surface Rights Board Act ${ }^{161}$ and the Umbrella Final Agreement. The YSRB is required to determine whether access is reasonably required to Yukon Settlement Lands (or to other private land) in order to exercise subsurface rights. The YSRB also has the power to establish terms and conditions for access and to determine compensation for disturbance caused by the access. The YSRB must follow specific rules in exercising its powers with respect to Yukon Settlement Lands. Unlike the Surface Rights Board in Alberta, the YSRB may issue an order for access to conduct seismic surveys.

The board will not accept an application unless the applicant demonstrates to the satisfaction of the board that it has made efforts to negotiate a settlement. ${ }^{162}$ The board's rules specify the contents of a negotiation record. It appears that this requirement is intended to apply in respect of applications by First Nations as well as by others; however, the Yukon Surface Rights Board Act is not clear on this point. As the board may not make an order in respect of a matter that is not raised by any of the parties, any party bringing an application to the board must be sure to fully and carefully set out the relevant issues.

On Crown lands and private (non-First Nation) lands, the $T L A$ and the $T L U R$ regulate land use. Water use is governed by the Yukon Waters Act. ${ }^{163}$ The Yukon Waters Act and accompanying regulations establish two categories of licence(Type $A$ and Type B). Public hearings are generally required in respect of Type $A$ licences, and they are held in respect of Type B licences when the Yukon Water Board is of the opinion that it is in the public interest. The Yukon Water Board administers the Yukon Waters Act, and it cannot issue a water licence until it is satisfied that the applicant has or will carry out certain obligations.

Finally, the Yukon First Nations with concluded Final Agreements will manage land and water use required for oil and gas activities in accordance with the Final Agreements and land and water use laws made by the First Nation. To date no such laws have been made.

\section{OfFShORE BRITISH COLUMBIA}

\section{A. HISTORY}

There has been very little exploration off the British Columbia coast. A team led by Richfield Oil Corporation conducted the first oil and gas exploratory activity in the British Columbia offshore area in 1958. They drilled five onshore wells on Graham Island in the Queen Charlotte Islands. This drilling program was followed by marine seismic surveys

l61
l62 S.C. 1994, c. 43.
163 Sid., S. 26.
S.C. 1992, c. 40.


in Hecate Strait, further onshore seismic surveys, and the drilling of a sixth well in $1961 .{ }^{164}$

The most significant exploration project to date has been the exploratory drilling that Shell Canada Ltd. ("Shell") conducted in Queen Charlotte Sound and Hecate Strait between 1968 and 1969 . The results of these exploratory wells were disappointing. The last exploration activities were carried out in 1972.

Notwithstanding these efforts, optimism about British Columbia's offshore oil and gas potential remains high. There appears to be some support for this optimism. In 1998 the Geological Survey of Canada estimated that 9.8 billion barrels of oil and 40 trillion cubic feet of gas exist in the Queen Charlotte Basin. ${ }^{165}$

\section{B. THE MORATORIUMS}

In 1959 the Province of British Columbia purported to create a Crown reserve over petroleum and natural gas underlying the offshore area between the British Columbia mainland and a line approximately three miles off the west coast of the Queen Charlotte and Vancouver Islands. This included the whole of the area between Vancouver Island and the Queen Charlottes, but excluded those areas that were held under existing exploration permits. This was followed by a series of further Orders in Council.

In 1972 the federal government passed an Order in Council relieving existing permit holders from their obligations to conduct exploratory drilling and prohibiting any further drilling. This order was followed by a provincial government Order in Council in 1981 declaring an Inland Marine Zone, and placing an indefinite moratorium on offshore exploration in Johnstone Strait, and in the Straits of Georgia and Juan de Fuca. ${ }^{166}$

In 1983 PetroCanada prepared an Initial Environmental Evaluation ("IEE") to advocate the removal of the moratorium and the resumption of offshore drilling activities. The IEE prompted the federal and British Columbia governments to re-examine the need for the moratorium. In June 1984 the federal and British Columbia Ministers of Environment appointed a five-person panel called the West Coast Offshore Exploration Environmental Assessment Panel (the "Panel"). ${ }^{167}$ The Panel was asked to develop terms and conditions under which offshore exploration efforts could resume.

The Panel released its report after two years of hearings and investigations. The report stated that exploration efforts off the British Columbia coast could be allowed to resume provided that a rigorous environmental protection regime was developed. The Panel made ninety-two recommendations that they believed should be adopted before this happened.

West Coast Offshore Exploration Environmental Assessment Panel, Offshore Hydrocarbon Exploration Report (Vancouver: The Panel, 1986) 9 [hereinafter Westcoast Report] at 9.

P.K. Hennigan, et al., Petroleum Resource Potential of Sedimentary Basins on the Pacific Margin of Canada (Calgary: Geological Survey of Canada, 1998) at 64.

lbid. at 9.

lbid. at 1. 
In June of 1987 the federal and British Columbia governments released a joint response to the Panel's report. The governments accepted a majority of the Panel's recommendations. At the same time, both governments announced an intent to lift the moratorium pending the finalization of what was described as the "Pacific Accord." 168

In 1987 the provincial energy minister announced that the Pacific Accord had been all but finalized. However, the finalization never took place. In 1989 the Exxon Valdez oil spill off the Alaskan coast and the spill from the tug Nestucca off Grays Harbour, Washington prompted the continuation of the moratorium(s).

\section{Current Status of British Columbia Offshore ACtivity}

Recently, there has been renewed discussion of oil and gas exploration and production off the British Columbia coast. In 1999 the Northern Development Commission, a British Columbia government agency, commissioned a study into the prospect of "constructing an appropriate process surrounding consideration of the existing moratorium on offshore oil and gas exploration." 169

This study canvassed the opinions of approximately 140 people involved with interested groups and concerned individuals. The study concluded that there was significant community interest and desire to go forward into a consensus-based process that would consider the potential of lifting or keeping the current moratorium. However, it also recommended that the study be expanded to "gauge the will and interest of industry and the people of the rest of the Province before gauging the will of government."170

An expanded study is currently underway to canvass the views of industry, various levels of government, environment groups, and representative groups from other jurisdictions where offshore drilling has taken place. This study is designed to provide an indication of the parties who are willing to participate in a public process to consider the issue, the information and expertise they can bring to the process, and suggestions regarding how that process would be constructed. ${ }^{171}$ The second phase of the study is anticipated to be completed sometime in June 2000. The Commissioner of Northern Development hopes to make a recommendation to government in July $2000 .^{172}$

It should be noted that the provincial government has not in any way agreed to be bound by these recommendations or to address this issue in any given time frame. Furthermore, the studies that have or are being undertaken are a provincial initiative; no

171

for a presentation by Northern Development Commissioner

172 Personal communcation from J. Backhouse, Northern Development Commissioner (May 2000).

British Columbia, Status of the Federal-Provincial Government Response to the West Coast Offshore Exploration Environmental Assessment Panel Report (Victoria: Ministry of Energy, Mines and Petroleum Resources, 1988) at 2.

Report to the Northern Development Commissioner from the Conflict Manager's Group (15 September 1999), online: <http://www.ndc.gov.bc.ca/Report/oilgasreport.htm> (last modified: 22 June 2001).

lbid. 
indication exists to suggest that the federal government has participated in this initiative, or to suggest its current view on the federal moratorium.

\section{The Future of British Columbia OfFShore OIl and Gas Development}

In addition to environmental concerns, two additional matters will likely influence both whether and when oil and gas exploration can take place off the British Columbia coast: the requirement for a provincial/federal accord; and the effect of aboriginal rights and title. Each of these is discussed briefly below.

\section{PROVINCIAL/FEDERAL ACCORD}

The issue of jurisdiction over offshore oil and gas interests in British Columbia is unresolved. At law, it is clear that British Columbia has ownership of the subsurface resources that lie under the body of water that separates Vancouver Island from the British Columbia mainland. ${ }^{173}$ It is also clear that Canada owns, and/or has jurisdiction over, the territorial sea and continental shelf off the coast of British Columbia. ${ }^{174}$

However, some disagreement existes regarding where the "territorial sea" begins. That is, does it start at the British Columbia mainland or somewhere roughly parallel to a line between the west coast of Vancouver Island and the Queen Charlottes? The former would result in a significant proportion of the British Columbia offshore area being within federal ownership and jurisdiction; whereas the latter would result in British Columbia having ownership and control over those resources.

Because of this unresolved question, because of the existing division of jurisdiction over these resources, and because of the legitimate interests of both the provincial and federal governments in offshore oil and gas development, it appears clear that some form of provincial/federal accord is necessary before development can occur. Given that similar accords have been reached between the federal government and both Newfoundland and Nova Scotia, this does not appear to be a major stumbling block.

\section{ABORIGINAL RIGHTS AND TITLE}

Perhaps more significant legal issues that will affect if and when British Columbia offshore oil and gas development will take place are aboriginal rights and title, and the current aboriginal land claims process underway in British Columbia.

A full review of the law with respect to aboriginal rights and title is beyond the scope of this article. Briefly stated, an aboriginal group may have aboriginal rights to conduct certain activities that were an integral part of that First Nation's culture prior to European contact. ${ }^{175}$ In addition, an aboriginal group may have aboriginal title to areas that they

$175 \quad$ R. v. Van der Peet, [1996] 2 S.C.R. 507. 
occupied prior to $1846 .{ }^{176}$ Aboriginal rights and title are constitutionally protected and can only be infringed by government if the infringement is justified. ${ }^{177}$ Where aboriginal title exists, this may require the consent of the aboriginal group before any infringement takes place. ${ }^{178}$

Many aboriginal groups reside on the British Columbia coast. It is likely that a significant number of these groups have aboriginal rights that may be affected by offshore oil and gas activity. This would require that these groups be "consulted" with respect to this activity. A full review of the requirements of consultation to justify an infringement of aboriginal rights is beyond the scope of this article. However, this is an area that would be ripe for a legal challenge if aboriginal groups were opposed to this activity.

It is less likely, but still possible, that an aboriginal group could claim aboriginal title to an area that may be affected by offshore development. As mentioned above, this may then require that group's consent before proceeding with offshore development. This again suggests that significant legal uncertainties must be resolved before this type of activity could be undertaken.

While aboriginal rights and title are unlikely to be an absolute bar to British Columbia offshore development, litigation surrounding these issues could prevent this development for a significant period of time. While some attempt is being made to resolve issues of outstanding aboriginal rights and title through the British Columbia treaty process, significant concerns remain about the ability of this process to resolve these issues. This suggests that even if British Columbia offshore development can overcome other hurdles, the issue of aboriginal rights may significantly affect this development for an extended period of time.

\section{v. CONCLusion}

This article has provided a brief overview of the current regulatory regimes in the Northwest Territories, the Yukon and offshore British Columbia. It has also attempted to review some of the primary influences underlying the development (or future developments) of these regimes.

As indicated above, exploration for and development of, oil and gas in the Northwest Territories, the Yukon and offshore British Columbia present an array of physical, social, economic, and legal challenges. Although the developing regimes in these areas are different than existing regimes, they are not unworkable. In fact, it could be argued that because of the role of community input into these regimes, particularly through land claim agreements, developments which proceed through these regimes will be more acceptable to a broader range of stakeholders and less susceptible to legal challenges. This could be significant given the relative magnitude of the projects in these developing areas, and given other challenges associated with them.

\footnotetext{
17. Delgamuukw v. British Columbia, [1997] 3 S.C.R. 1010 [hereinafter Delgamuukw].

$177 \quad$ R. v. Sparrow, [1990] S.C.R. 1075.

178 Delgamuukw, supra note 176.
} 
These regimes will significantly affect the manner in which oil and gas companies operate in these areas. While the legal frameworks in each of the Inuvialuit, Mackenzie Valley, and the Yukon are different, each of these respective processes will require longer lead times to obtain the necessary approvals before any oil and gas activity can take place. It will also increase the amount of information that an oil and gas company must share with respect to its planned activities. These considerations will affect the nature and type of companies or other undertakings able and willing to participate in these processes.

It appears that the primary objective of these processes is not to design a process that was optimal from an oil and gas industry perspective. Rather, the objective is to find processes that reflect the way in which local interests are prepared to have development activity take place in their communities. It remains to be seen whether this objective and industry's objectives can co-exist. 